\title{
Use of Evaluation Indicators in the Composition of the Consolidated Financial Statements in Digital Format of Economic Space
}

\author{
N. N. Khakhonova \\ Department of accounting \\ Rostov state University of Economics (RSUE) \\ Rostov-on-don, Russian Federation \\ n_khakhonova@bk.ru \\ N. Yu. Koroleva \\ Department of taxes and taxation \\ Rostov state University of Economics (RSUE) \\ Rostov-on-don, Russian Federation \\ knu70@mail.ru
}

\author{
Yu. N. Kirkach \\ Department of auditing \\ Rostov state University of Economics (RSUE) \\ Rostov-on-don, Russian Federation \\ kirkach-ulya@mail.ru \\ S. G. Agabekyan \\ Department of economic and humanitarian disciplines \\ Rostov state University of Economics (RSUE) \\ Kislovodsk, Russian Federation \\ audit703@rsue.ru
}

\begin{abstract}
The article considers the advantages of including estimates in the consolidated financial statements. The authors include the risk premium, the inflation rate, and the company's credit position to the estimated indicators. These indicators play an important role in the overall assessment of the company's investment attractiveness in the context of the digitalization of the economy and the use of cryptocurrency. The risk premium provides certain guarantees of profit for investors, regardless of the yield of securities. It is expected that the higher the yield of the security and, accordingly, the level of danger, the greater the risk premium can be received by the investor. The inflation rate allows to adjust the value of the company's assets at the current moment. The assessment of credit position allows to understand how the discount rate and the cost of liabilities will change. The use of these indicators will allow to evaluate the current value of the company's assets, the level of its solvency and present the final indicators in the consolidated financial statements.
\end{abstract}

Keywords: performance indicators, rate of inflation, the risk premium, credit position, consolidated financial statements

\section{INTRODUCTION}

In the context of digitalization of the economy, one of the key factors of an economic entity development is the implementation of innovative technologies in its activity. Many companies in their work use digital currencies as means of payment. This accounting object is not regulated by the legislation of Russian Federation. Accordingly, the operations with cryptocurrencies are considered to be risky, and in case of cryptocurrency's failure, the risk of the company's insolvency increases $[1,2,3]$. This fact propels investors to consider carefully the feasibility of investing funds in the organization, realizing payments with cryptocurrency. This circumstance forces companies to reveal the indicators in the consolidated financial statements, in which investors could evaluate the benefit and the correctness of committed investments, and also increase the company's confidence and reliability.

\section{MAterials AND Methods}

In the digital economic space the indicators of financial statements of economic entities will form using a number of perspective methods and technologies such as: cloud accounting, mobile applications, artificial intelligence, etc. This will expand the range of using indicators, having complementary diagnostic or predictive value, in particular, estimated indicators as a kind of financial well-being indicators

In the process of research, not only general scientific methods, but also specific methods were used. For example, methods for determining the perimeter of consolidation of consolidated financial statements. The perimeter of consolidation allows to define the indicators of which companies, entering into group of companies, are included in the composition of the consolidated financial statements.

The use of these methods let to achieve goals and get the following results. 


\section{RESULTS}

Having studied the reports of companies of different industry sectors (Public joint stock company «Gazprom», Public joint stock company «Lukoil», Open joint-stock company «Russian railways») and conducted comparative characteristic, it was installed that the indicators reflected in the explanations, undoubtedly, differ. This is facilitated by such facts as:

1. Industry specifics;

2. The absence of certain accounting items in the company;

3. The application of the professional opinion of prepares of report regarding the recognition of the significance and insignificance of any information and the necessity for its disclosure in the composition of the consolidated financial statements.

It should be remembered, that according to paragraph 4 of The regulations on accounting «Information on segments» 12/10: "the disclosure of information by segments must provide interested users of the company's accounting (financial) statements with information that allows them to evaluate the industry specific activity of the organization, its economic structure, the distribution of financial indicators in certain areas of activity». Definitely, the consolidated financial statements demonstrates the above-mentioned directions of the company's work. However, the indicators exist in conditions of the destabilization and the digitalization of international economy, which, from our point of view, regardless of the industry, must be taken into account when forming the consolidated financial statements. According to authors, premium risks on shares, the rate of inflation and the revaluation of the company's credit position relate to them. It's expected that these indicators will let investors to estimate the correctness of the investments in the company.

As a result of the research it was found, that the indicators' integration into the unified consolidated financial statements of the group of companies is the next action. For this it's necessary to define the set of indicators, which, regardless of industry affiliation, have a significant impact on the objectivity and credibility of the company's financial condition and increase the investors'informativeness.

The authors concluded that the following indicators must be mandatory reflected in the notes to the consolidated financial statements to present realism in the financial statements and to increase investors' awareness:

1. The risk premium in shares;

2. The result of revaluation of the company's credit position;

3. The inflation rate.

Presented indicators are appropriate and useful for making investment decisions in a non-permanent digital economic space. At the same time, methods of evaluating and calculating these indicators should be reflected in the parent company's accounting policy. As the financial statements is primarily intended for the satisfaction of shareholders' and other investors' information needs, Hendriksen E.S. and Van Breda M.F note that «the reporting must provide sufficient information to get the view of future dividends on its basis and the opportunities for profit from exchange operations» [4]. From our point of view, the proposed indicators (the risk premium, the assessment of the company's credit position and the indicators' adjustment based on the current rate of inflation) let stakeholders to make a real assessment of the company's financial condition in terms of digital data. Economic entities that disclose the actual risks in their consolidated statements, the strengths and weaknesses of the company, increase the confidence of stakeholders, which provides the investment inflow and, as a result, the value of the company grows. Therefore, the compilation of the consolidated financial statements will improve the quality of provided information and will have a significant impact on investments inflow taking into account the proposed significant accounts.

\section{DISCUSSION}

Without claiming to provide an unambiguous solution to the problem posed in the study, however, we would like to argue in more details our position and the findings.

At the moment, in accordance with the current legislation, almost all large economic entities form and submit to the users consolidated statements. For its compilation, developers must conduct a lot of work on collection, processing, unification and visual information presentation of dozen of units, branches, subsidiaries, etc. The information reflected in these statements, requires transparency because the indicators are presented to the stock markets, investors and are the basis for management decisions.

Federal law №208-FZ «On consolidated of financial statements» issued in 2010 required many Russian companies to report consolidated financial statements according to international standards of financial statements which build a certain sequence of their formation. The first step of creating consolidated financial statements is the definition of the consolidation perimeter, in which, in addition to the parent company and subsidiaries, associated and jointly controlled companies can also be included. According to the international practice in the process of consolidation the key moment is the control's definition: consolidation of an investment object starts from the moment when the investor losses his control over the investment object.

Today in the international practice two methods of consolidation are used: the method of full consolidation and the equity method. Choosing one or another consolidation method, company, primarily, should analyze the account «Financial investments» and set up the presence of attachments in three types of companies: subsidiaries associated and jointly controlled companies.

If a company invests in the subsidiaries, then the full consolidation method, which is based on the concept of a «single enterprise», is used in the preparation of financial statements that is the group of companies is one legal entity because assets, liabilities, incomes and expenses are controlled by the whole group [5]. According to this method, the 
indicators of consolidated statements are obtained by summing up the indicators of all subsidiaries except the results of internal operations. This method, at this moment, is one of the most widespread [6].

When a company invests in associated or jointly controlled companies, the equity method is used, the essence of which is that the investments are initially recognized at original cost, and then their value is taking into account changes in the investor's share in the net assets of the investee after acquisition. The investor's profit or loss includes the investor's share in the profit or loss of the investee, and other total income of the investor includes the investor's share in the other comprehensive income of the investee. Correspondingly, the indicators of the dependent enterprise are not included in the consolidated statements of the group because control's degree is not enough for it [7]. Russian companies often use the full consolidation method in the process of creating a consolidated financial statements' structure.

Having combined these groups of companies in the consolidated financial statements, it is necessary to complement the explanations for the consolidated financial statements with such indicators as the risk premium, the rate of inflation and the revaluation of the company's credit position. This conviction was based on the following judgment.

There is no doubt that the main investor's aim is increasing the value of the investment portfolio, and the growth of investor's potential profit due to the selection of the most promising securities, in particular shares. Dividends on allocated shares are the main benefit of the depositor, which is paid according to the results of a certain period of time on the basis of the decision of the general meeting of shareholders or the general meeting of the company's participants. However, it should be noted that there is such a benefit as a risk premium, which should be understood as the amount of money, which an investor additionally gets for performing risky operations. The mentioned factor is one of the main ones, which today is being considered by investors when choosing the optimal opportunity to invest their funds. In fact, the non-payment premium compensates the investor for the possibility that the company will not pay the promised amounts.

Undoubtedly, the investors will invest in that company which will provide for the payment of premium for risks because it is an additional profit to the amount that is paid for risk-free transactions, that is dividends. That's why purchasing company securities, we believe that it is necessary to give priority exactly to shares since other securities, for example, bonds are often less profitable and simultaneously more stable in terms of the size and time of instrument payouts. In turn, the shares are more risky type of investment and their price can change very much during the year, but their income is higher, as the rule [8].

The methodology for risk premium calculation should be registered in the corporate accounting policy and, as the rule, it is defined as the difference between the expected profitability of investments with a risk - free interest rate and is expressed as a percentage. Nevertheless, there is a direct correlation: the higher is the yield of the security and, correspondingly, the level of danger, the greater the risk premium an investor can get.

Another important indicator, from our point of view, is the inflation rate for the reporting period. Today the fall of the purchasing power of the Russian currency and the growth of foreign exchange rates, in particular dollar and euro, happens in the period of destabilization of Russian economy due to sanctions. According to the statistical information, the normal value of the company's profitability is $10-12 \%$. This value refers to America and England. In relation to the Russian economy, this indicator should be higher. To maintain financial stability companies have to reveal the information in the consolidated financial statements taking into account such macroeconomic indicator as inflation. In fact, the fall of the purchasing power of a monetary unit, alongside with rising prices, has a huge impact onto the work with the investors, contractors and other interested parties.

Taking into account the fact that the Russian economy is inflationary, a number of economists like Efimova O.V, Kaspina R.G. and Loginov A. S., Kuvaldina T.B., Rudakova T. A., Khakhonova N.N. and Krutskikh R.V, [9,10,11,12] and others, note fairly that «enterprise's property realizing its activity in terms of an inflationary economy, acquired several years ago and reflected in financial statements at acquisition prices, at that moment this will have absolutely another cost significantly differing from its book value» [13]. It is difficult to disagree with this statement because many indicators in the consolidated financial statements are reflected at purchase prices, excluding inflation that gives a distorted picture of the company's assets value and causes the need to reflect inflation in the consolidated financial statements.

Another important advantage for investors in reflecting inflation in the consolidated financial statements is the fact that inflation's tendencies predetermine the interest rate aspiration, which play the key role in predicting the share's prices and bonds, and, respectively, in developing the appropriate action's tactic. As noted by Selezneva N.N. «various securities react differently to inflation, for instance, zero - coupon bonds are not protected at all from the risk of losing its purchasing power, but shares provide more reliable protection against inflation. It is one more positive moment stimulating investors to buy particular shares. If investments occur only in shares, then inflation does not particularly affect such investments: as a rule, large companies and their shares are resistant to inflation: their profits will «catch up» with the inflation in the long term. On the contrary, the elevated level of inflation is especially disadvantageous for bondholders because their money is stored in fixed instruments with a fix rate and they suffer losses. Accordingly, the inflation negatively affects bonds and deposits since the profit on them is clearly defined and does not change over» [14]. Therefore it is very important for investors to bear in mind the inflation's rate in investing in order to know real profit from investments.

Thus, there is a direct dependence between inflation and investment: the higher is the level of price growth, the less the investor gets the real profit because the inflation absorbs the profit from investments. The investor tracks the inflation's rate 
position. It is assumed that the deterioration of the company's credit position reduces the size of the commitment (debit) and the organization's profit is recognized in credit. Paradoxical as it may sound, the company profits from the deterioration of its financial position. Cheremushkin S.V. also notes that «today the change of company's credit position does not always reflect in accounting, because commitments are recognized in accounting at initial recognition» [15]. Respectively, reporting obligations information is distorted and does not give a real state of affairs in the holding. Consequently, we consider that it is necessary to assess the credit position annually taking into account risks and reflect changes of credit position in the consolidated financial statements to create a real picture of financial and economic company's condition. Performing such manipulations, compliers should not be afraid of the outflow of investments because the company benefits from an improvement of its credit position in terms investment inflows, the company wins by reducing the size of commitments in the deterioration of the credit position. If the company's non- payment risk in the future increases and the discount rate increases, then the lenders try to sell the company a commitment at the proposed size, since they are likely to remain at a loss. If the company's credit position improves, then, accordingly, the discount rate for this commitment reduces and if the company wants to redeem its commitment, it will have to spend more money because the lender will not want to sell to the company its commitment at a lower price, taking into account risks. That's why today it is necessary for stakeholders to focus not on the absolute size of debt commitments, but on borrowing rate and the default's risks.

Revaluation of the company's credit position should also be carried out due to the change of the inflation's rate because it has a direct impact on the terms of loans and credits and it is often impossible to predict in whose favor the terms will change.

It should be noted that not all significant factors will be considered substantial but the indicators we have highlighted have a known impact on the creation of value in the company, therefore, from our point of view, they need to be taken into account when forming the consolidated financial statements. So the risk premium indicator paid to investors in the reporting period should be reflected as a percentage. The demonstration of this indicator will help investors to make the right decision on making deposits to the company, and the accountants and analysts to predict the risks for the future, which will be reflected in tactical report.

Since inflationary processes have a big impact on investment decision-making and the reliability of reporting in general, for compilers it is important to take into account the inflation factor in generating reports, to evaluate its consequences and adapt to them for the future reporting period. These planning indicators will be also reflected in the corporation's tactical report. 
[8] T. Fomchenkov, "Risk premium. Foreigners rated the Russian stock market", Russian newspaper-Federal issue, no. 110 (6978), 2016 [Electronic resource]. Available at: https://rg.ru/2016/05/23/rossiiazaniala-vtoroe-mesto-po-razmeru-premii-za-risk.html (Accessed: 02.12.2019)

[1] I.N. Bogataya and E.M. Evstafyeva, "Accounting digitalization of accounting: expectations and reality", Audit, no. 11, pp. 21-26, 2019.

[2] T.B. Kuvaldina, "Influence of digitalization of the economy on accounting", Economic and humanitarian sciences, no. 4 (327), pp. 2331, 2019.

[3] V.V. Priobrazhenskaya, "Influence of the digital economy on the development of competencies in the field of accounting", Financial journal, no. 5, pp. 50-63, 2019.

[4] E.S. Hendriksen and M.F. Van Breda, Accounting theory: translation from English under the editorship of prof. J. V. Sokolov. M: Finance and statistics, 2000.

[5] V.S. Plotnikov, O.V. Plotnikova, V.I. Melnikov, and V.A. Moskaleva, "Method of full integration of accounts in consolidated accounting and reporting", International accounting, no. 46, pp. 2-19, 2015.

[6] N.S. Kostyuchenko, "Consolidated financial statements of the group", Journal of Risk Granter, no. 10, 2013 [Electronic resource]. Available at: $\quad$ http://www.riskovik.com/journal/stat/n10/otchetnost-gruppy (Accessed: 06.12.2019)

[7] N.V. Generalova, "The technique of preparation of consolidated financial statements according to IFRS", Buch.1C Internet resource, 2014 [Electronic resource]. Available at: https://buh.ru/articles/documents/38717/ (Accessed: 07.12.2019).

[9] O.V. Efimova, "Method of calculating inflation in the analysis of financial statements", Accounting, no. 10, pp. 45-49, 2003.

[10] R.G. Kaspina and A.S. Loginov, "Issues of adjusting financial statements in terms of inflation", International accounting, no. 6 (42), pp. 2-7, 2002.

[11] T.B. Kuvaldina, Cost accounting in the conditions of inflation. Omsk: Apelsine, 2010.

[12] T.A. Rudakova, "Influence of the inflation phenomenon on financial reporting indicators", International accounting, no. 1 (199), pp. 20-28, 2012.

[13] N.N. Khakhonova and R.V. Krutskikh, "Identification and classification of methods for accounting for the impact of inflation", Financial study, no. 1, pp. 86-92, 2016.

[14] N.N. Selezneva, Financial analysis. Financial management. Moscow: UNITY-DANA, 2015.

[15] S.V. Cheremushkin, "Features of recognition, evaluation and interpretation of liabilities in financial statements in accordance with USGAAP and IFRS, taking into account the credit position of the company", Economic analysis: theory and practice, no. 4 (169), pp. 24$36,2010$. 